\title{
Finding About Event or Intervention Test
}

National Cancer Institute

\section{Source}

National Cancer Institute. Finding About Event or Intervention Test. NCI Thesaurus. Code C87892.

A character or string that represents a finding of the event or intervention. 